\title{
URGENSI KURIKULUM PENDIDIKAN AGAMA ISLAM DALAM FENOMENA RADIKALISME DI INDONESIA
}

\author{
Muhammad Nur Adnan Saputra', Muhammad Nurul Mubin² \\ Universitas Islam Negeri Sunan Kalijaga Yogyakarta \\ Universitas Islam Negeri Sunan Kalijaga Yogyakarta \\ Email; Adnansaputra7@gmail.com;mnmubin96@gmail.com
}

\begin{abstract}
The phenomenon of radicalism in Indonesia has recently become increasingly commonplace, there are many intolerant activities taking place in various layers of society. In particular, the radicalism carried out by elements who divide the ummah from the Islamic group, has made the image of Islam as a religion of peace for all nature and incompatible with a tolerant and moderate Islamic person. Not to mention that the understanding of intolerance has begun to be detected in educational institutions, many educational institutions are infiltrated with radical and intolerant views. Therefore, this study wants to describe how urgent the deradicalization program is in the curriculum in Indonesia. How is the concept of deradicalization in the curriculum, and how to deradicalise the existing curriculum in Indonesia. This study aims to determine the concept of deradicalization in the curriculum, as well as how to deradicalise existing curricula in Indonesia. The research method uses literature studies by collecting data from documents using descriptive-analysis methods. Deradicalization of the curriculum in Indonesia is very depleted, deradicalization in education can be carried out with a pedagogical approach through careful planning in the curriculum for learning Islamic religious education. In Indonesia, the government has begun to promote curriculum deradicalization with the Strengthening Character Education.
\end{abstract}

Keywords: Curriculum,Urgency, Deradicalization, Education

\section{PENDAHULUAN}

Belakangan ini publik digegerkan dengan berita di media cetak maupun media sosial mengenai banyaknya kasus inteloran yang terjadi di masyarakat.Seperti pembakaran salah satu masjid di kota besar (Muhyiddin, 2017). Kegiatan intoleran tersebut merupakan salah satu indikasi menerobosnya pemahaman eksklusif dalam sebuah tatanan masyarakat yang plural di Indonesia.

Terdapat dua faktor utama yang sama besarnya dalam mempengaruhi berkembangnya radikalisme dan terorisme di Indonesia, yaitu faktor dalam diri manusia maupun luar diri manusia. Faktor dalam diri manusia yaitu berupa keberagaman, sedangkan faktor luar berupa sosio-politikultural, faktor psikologis, dendam politikultural, faktor sejarah, faktor pendidikan, faktor pemikiran, faktor ekonomi, faktor sosial, serta faktor politik. 
Selain faktor di atas, terdapat faktor lain, yaitu: makna literal Al-Qur'an, sporadis, serta pemahaman agama parsial. Kesalahpahaman sejarah Islam ditambah dengan idealisasi Islam yang berlebihan dalam kurun waktu tertentu, kalangan politik, sosial, serta ekonomi yang masih terus berlanjut di masyarakat(Isnawan, 2018). Selain itu, penyusupanpahamdi masyarakat juga terjadipada bidangpendidikan. Meskipun pendidikan bukanlah penyebab langsung dari gerakan radikal, namun konsekuensi dari pendidikan yang ceroboh juga sangat berbahaya. Pendidikan agama khususnya, membutuhkan perhatian lebih karena jarangmengajarkandoktrinagamamengenaitoleransi,persatuan,keramahtamahan,sertamengh apuskebencian.

Naik turunnya alur pendidikan yang disampaikan kepada orang-orang lebih bersifat ejekan daripada anjuran, lebih banyak gempuran daripada dekapan, serta sering melabrak daripada membimbing. Oleh karena itu suatu generasi merasa bahwa dirinya serta kelompoknya adalah yang lebih benar, sedangkan yang lain salah seluruhnya. Ini adalah dampak dari kesalaham sistem pendidikan.Kurikulum agama terpaksa dimasukkan dalam kurikulum umum, serta sekolah umum merasa khawatir dengan masuknya kurikulum agama.

Adanya penyusupan pemahaman intoleran terjadi di dunia pendidikan merupakan sebuah fakta yang sungguh ironis.Dunia pendidikan yang seharusnya adalah tempat menggali ilmu pengetahuan, tetapi "terpaksa" disusupi pemahaman yang berpotensi merusak bangsa yang berbhineka ini.Salah satu contoh bentuk penyusupan paham di dunia pendidikan adalah adanya sebuah institusi pendidikan dasar di daerah Yogyakarta dimana anak didiknya diajarkan sebuah yel-yel "Tepuk Islam" yang bernada rasis.Cuplikan redaksi dari yel-yel tersebut adalah "Kafir! Kafir! No!, Islam! Islam! Yes." Hal ini tentu memprihatinkan bagi orang tua, karena terdapat penyisipan pemahaman intoleran semenjak usia dini, dengan cara anakanak diajari untuk membenci kaum lain di luar Islam dengan ujaran katakan No pada Non Muslim(Hadi, 2007).

Terdapat kasus lain di dunia pendidikan yang juga mengarah pada penyusupan paham intoleran. Di dinas pendidikan salah satu kabupaten di Bangka Belitung terdapat kewajiban membaca serta mengkaji buku "Muhammad Al-Fatih 1453" karya Felix Siauw yang dianggap sebagai tokoh Hizbut Tharir Indonesia (HTI). Seperti yang diketahui bersama bahwa HTI merupakan sebuah organisasi yang dilarang dan berindikasi menyusupkan paham-paham radikalisme di Indonesia (Wahyono, 2020).Dua contoh kasus ini tidak lepas dari kurangnya perhatian publik dan peran pemerintah terhadap pendidikan agama, serta mengindahkan bahwa tindakan radikal merupakan masalah serius yang dihadapi bangsa Indonesia.

Banyaknya faktor yang mempengaruhi menjamurnya paham intoleran dan beberapa kasus penyusupan paham radikal di dunia pendidikan tentu memerlukan adanya sebuah 
sistem yang mengatur agar dapat menangkal secara prefentif tindakan yang dapat memberikan dampak buruk bagi masa depan pendidikan Indonesia. Dalam proses pencegahan dan pengurangan radikalisme diperlukan metode lain yaitu soft form (metode lunak), dalam hal ini melalui kursus pendidikan agama. Dalam kursus pendidikan agama, tidak hanya kegiatan akademik formal yang harus diperhatikan, tetapi juga kegiatan informal.

Pada pelaksanaannya, kurikulum 2013 belum menyediakan buku panduan untuk pelajar sehingga mereka harus aktif mencari materi pelajaran di internet (Hergianasari, 2019). Dengan pencarian materi pelajaran di internet, tentu tanpa saringan ideologi.Hal ini berakibat pelajar berpotensi lebih besar memeroleh materi pelajaran yang telah disusupi paham radikal, yang berimbas pada tindakan radikal, karena kesalahan dalam memahami materi.Maka untuk menghadapi hal tersebut diadakan upaya deradikalisasi melalui kurikulum pendidikan agama Islam dalam mewujudkan pengenalan, terintegrasi dalam silabus, bahan ajar, dan RPP. Hal yang sama juga diterapkan pada pendidikan agama Islam yang melakukan inovasi dan perubahan pada kurikulum guna menghasilkan lulusan yang memiliki akhlakul karimah (Achadah, 2020).

Menurut Undang-Undang SISDIKNAS nomor 20 tahun 2003 bab 1 pasal 1 ayat 19 . Kurikulum adalah seperangkat rencana dan pengaturan mengenai tujuan, isi, dan bahan pembelajaran serta cara yang digunakan sebagai pedoman penyelenggaraan kegiatan pembelajaran untuk mencapai tujuan pembelajaran tertentu (SISDIKNAS, 2003). Kata kurikulum berasal dari bahasa Yunani yang semula digunakan dalam bidang olahraga, yaitu currere yang berarti jarak tempuh lari, jarak yang ditempuh dalam lomba lari.Pengertian ini kemudian diterapkan dalam bidang pendidikan.Dalam bahasa Arab, istilah kurikulum diartikan manhaj yang berarti jalan yang terang, atau jalan terang yang dilalui manusia pada bidang kehidupannya. Dalam aspek pendidikan, kurikulum berarti jalan terang yang dilalui oleh guru dengan siswa untuk mengembangkan pengetahuan, keterampilan, sikap, serta nilai-nilai (Muhaimin \& et.al., 2010).

Upaya deradikalisasi melalui kurikulum berusaha mengenalkan kepada pelajar bahwa Islam selalu mengajarkan kedamaian, kerukunan, ketentraman kepada sesama umat Islam maupun yang berbeda agama.Dengan adanya kurikulum yang tepat, diharapkan dapat membentuk karakter siswa yang tidak radikal tetapi mempunyai nilai-nilai keagamaan yang kuat, mempunyai karakter cinta damai, dan selalu menjaga persatuan dan kesatuan bangsa Indonesia. Inovasi kurikulum pendidikan Islam bukan hanya dirancang sebagai program deradikalisasi semata akan tetapi untuk menyongsong beberapa tahun ke depan dengan menyiapkan generasi muda yang maju dan berkembang mempunyai kualitas unggul (Kisbiyanto, 2016). 


\section{METODE}

Penelitian ini menggunakan metode penelitian pustaka, yaitu suatu bentuk penelitian dengan menggunakan literatur yang meliputi buku, catatan, serta keterangan penelitian dari penelitian sebelumnya (Sugiyono, 2018).Dokumentasi adalah suatu metode untuk memperoleh data dan informasi berupa buku, arsip, dokumen, laporan, jurnal dan informasi berupa angka dan gambar tertulis, yang dapat mendukung penelitian sebelumnya. Sedangkan penelitian kepustakaan merupakan teknik pengumpulan data yang tidak diarahkan pada penelitian tetapi melalui dokumen. Dokumen yang digunakan dapat berupa buku harian, surat pribadi, laporan, risalah rapat, instruksi khusus tentang pekerjaan sosial dan dokumen lainnya. Oleh karena itu, selama ada keterkaitan dengan topik yang akan diteliti, semua dokumen dapat digunakan.

Penelitian ini, penulis mengidentifikasi ide atau temuan yang ada dalam buku, makalah, jurnal, serta karya ilmiah yang berkaitan dengan tema.Data yang diperoleh kemudian dianalisis dengan metode deskriptif.Metode deskriptif adalah langkah-langkah yang diambil dalam representasi obyektif dari realitas yang terkandung dalam pertanyaan yang sedang dipelajari. Atau juga dapat diartikan sebagai cara untuk mendeskripsikan semua konten yang terkait dengan subjek dengan cara ini untuk melacak serta mensistematisasikannya.

\section{HASIL DAN PEMBAHASAN}

\section{Radikalisme dan Deradikalisasi}

Pada dasarnya umat beragama hendaknya tidak membuatnya sempit, keras, kaku, serta tidak terbuka. Nasr, seorang tokoh filsafat perennial menegaskan semua agama memiliki kesamaan misi universal, meskipun menyangkut ritual dan pelaksanaan ajaran menunjukkan perbedaan.(Nasr, 1975)Karenanya, keberadaan agama selalu diiringi dengan "dua wajah".Di satu sisi, agama secara inheren memiliki identitas yang eksklusif, khusus dan primitif. Namun pada saat yang sama, agama juga memiliki identitas yang inklusif, universal dan transenden. Dengan kata lain, selain kekuatan pengikat (persatuan), keberadaan agama juga berpotensi sebagai kekuatan pemecah belah. Kekuatan pengikat agama terlihat pada ritual dan ibadah yang melahirkan persatuan sosial melalui praktek dan pengalaman bersama. Pada saat yang sama, ketika setiap pemeluk agama mengklaim bahwa doktrin agamanya adalah yang paling benar, agama mengandung kemungkinan perselisihan. Pengakuan kebenaran setiap pemeluk agama dapat menciptakan sikap eksklusif.

Dasar konstruksi berpikir dalam agama yang secara eksklusif ini bisa menjadi sasaran empuk untuk perkembangan radikalisme. Menurut Stark, karena salah satu faktor 
dasar yang mengarah pada radikalisme adalahketika agama difahami dan diajarkan dengan corak ekslusif partikularistik(Stark, 2003).Cara penyebaran agama ini pada akhirnya mendukung perkembangan partikularisme, percaya bahwa agama yang dianutnya adalah satu-satunya agama yang benar.Ciri-ciri tertentu dari transmisi faham Ilahi dengan corak ekslusif-partikularistik ialah penanaman keimanan yang kokoh dengan pendekatan doktrinernya, tanpa kompromi, dan normatif.Corak ini juga cenderung memposisikan diri secara berlawanan dengan faham yang berbeda dengannya.

Radikalisme, sebagai aliran atau ideologi, tidak serta merta muncul dalam diri seseorang. Itu membutuhkan proses pengenalan, pembinaan, apresiasi dan penguatan. Proses ini disebut radikalisasi bebas. Apabila radikalisasi bergerak tanpa rintangan, maka radikal akan menjadi ideologi atau gagasan, dan dengan demikian menjadi aktivis. Apalagi salah satu ciri dasar ideologi (isme) adalah menuntut pengikutnya untuk setia, yang biasanya berupa keberpihakan, pembelaan, dan pembuktian. Dalam hal ini, mudah untuk memahami apakah pengikut sekolah mampu melakukan beberapa hal yang terkadang berbahaya untuk loyalitas, menyimpang dari kebiasaan, tidak dikenal serta kompensasi kerusakan.(Karwadi, 2014)

Pada saat yang sama, deradikalisasi adalah proses mengubah sikap maupun pendapat yang menurut orang sulit untuk menjadi lembut, toleran, pluralistik, serta moderat. Oleh karena itu deradikalisasi adalah salah satu bentuk anti radikalisme.Jika radikalisme melahirkan radikalisme yang bercirikan sikap kaku, tangguh, dan tidak kenal kompromi, maka tujuan anti radikalisme adalah menjadikan seseorang lembut, toleran, beragam dan lembut. Radikalisasi dan deradikalisasi perlu ditekankan bahwa keduanya membutuhkan proses identifikasi, investasi, penghargaan, serta konsolidasi. (Karwadi, 2014)

Deradikalisasi berupaya untuk meminimalisir kejahatan, mencegah adanya paham radikal dengan menanamkan pemahaman agama melalui berbagai pendekatan, bersikap saling menghargai dan menghormati, bertindak sesuai hak dan kewajiban, serta cinta damai. Deradikalisasi memiliki tujuan mengenalkan, mengajarkan, dan menyadarkan bahwa sebagai panduan hidup yang diwujudkan melalui proses pendidikan dalam hal ini Pendidikan Agama Islam. Deradikalisasi dalam pendidikan dapat dilakukan dengan pendekatan pedagogis melalui perencanaan yang matang dalam kurikulum pada pembelajaran pendidikan agama Islam.Selain itu, deradikalisasi juga dapat dilakukan melalui pendekatan psikologis yang mengandung unsur kejiwaan peserta didik, dan pendekatan sosiologis untuk memberikan pemahaman kepada peserta didikdan masyarakat bahwa Islam merupakan agama yang damai, rukun, dan tolerani.Gagasan 
tersebut, secara tidak langsung mengatakan bahwa pelaksanaan deradikalisasi perlu melibatkan semua elemen.

\section{Konsep Deradikalisasi dalam Kurikulum}

Pendidikan merupakan sarana urgen serta efektif untuk mengajarkan norma-norma, nilai-nilai sosialisasi dan menanamkan etika profesi pada anggota masyarakat.Pendidikan juga dapat digunakan sebagai alat untuk menata perangai bangsa, mempertinggi serta memperkuat jati diri bangsa. Dengan memperkuat hubungan sosial dengan tetap menghargai keragaman budaya, ras, etnis, dan agama untuk meningkatkan integritas bangsa, pendidik dapat menjadi penghubung strategis untuk membangun kesadaran kolektif.(Musyarrofah, 2018)

Para ahli pendidikan percaya bahwa kurikulum memegang peranan penting dalam membentuk suasana sekolah, kepemimpinan serta kemampuan guru atau tingkat profesional. Di satu sisi, kurikulum akan menunjukkan arah pertumbuhan peserta didik dan akan mencapai tujuannya di lembaga pendidikan. Di satu sisi, kurikulum menjadi standar tindakan yang dilakukan pendidik bagi siswa. Oleh karena itu, kurikulum selalu digunakan sebagai pedoman ganda bagi institusi pendidikan dan pendidikan Indonesia dalam merencanakan serta melaksanakan proses pengajaran.

Secara subtansial, kurikulum dapat menjadi acuan dalam menginternalisasikan sebuah paham keagamaan.Sebuah hasil penelitian oleh Charlene Tan dalam Zainiyati yang dilakukan di sebuah pesantren di Ngruki, Solo, dan di Pondok Pesantren Tebuireng Jombang.Intinya, kurikulum ini bisa dijadikan rujukan untuk internalisasi pemahaman agama. Hasil studi Charlene Tan di Zainiyati dilakukan di sebuah pesantren di Ngruki, Solo, dan Pondok Pesantren Tebuireng di Jombang (Fikriansyah, 2019). Pada pesantren Ngruki, kurikulum ini, baik tertulis maupun implisit, bertujuan untuk membimbing mahasiswa menjadi bagian dari gerakan Islam serta menggunakannya sebagai sistem untuk menumbuhkan toleransi, pengekangan, dan cinta tanah air.

Kedua kemungkinan di atas menggambarkan peluang lembaga pendidikan menjadi wadah penularan radikalisme sebagai lawan yang moderat serta toleran.Oleh karena itu, lembaga pendidikan Islam harus mampu mengajukan mata kuliah yang bertujuan menumbuhkan kesederhanaan Islam. Relaksasi pemikiran atau ideologi individu atau kelompok yang terkena radikalisme, serta pemakaian bahasa lain untuk mengembalikan aktivitas mereka ke ideologi moderat disebut anti-radikalisme (Musyarrofah, 2018). Dalam upaya pemberantasan radikalisme, terbukti wacana tersebut mampu menempatkan bentuk pendidikan Islam yang lebih adaptif dan demokratis.

Islam sendiri adalah agama yang menerima segala perbedaan dalam literatur agamanya. Hormati setiap hal yang kompleks, dan bersedia berbicara dengan orang lain 
dengan segala yang dia yakini. Al-Qur'anmenjelaskan di dalam QS. Al-Hujurat: 13. "Wahai, manusia, kalian sebenarnya diciptakan oleh laki-laki dan perempuan, dan menjadikanmu bangsa dan suku sehingga kalian bisa saling memahami.Sungguh, yang paling mulia di sisi Allah adalah yang paling saleh di antara kalian. Allah tahu segalanya,"

Dialog tentang berbagai perbedaan merupakan upaya yang bertujuan untuk mempromosikan keyakinan dan pemahaman agama setiap orang. Islam tidak ingin sikap melihat dirinya sebagai sikap yang paling benar, karena dari kebenaran, Allah yang paling menentukan. Nabi Muhammad Saw.diperintahkan untuk menyebarkan Islam sebagai agama yang dapat menebarkan simpati kepada semua orang, hewan, dan tumbuhan. Seperti yang tertulis dalam "Quran": "Kami tidak mengirimmu, tetapi untuk penuh kasih sayang untuk alam semesta"(Q.S. Al-Anbiya' 928: 107) (Fikriansyah, 2019).

Kurikulum pendidikan Islam dengan toleransi multikultural dapat berupaya untuk menyelesaikan radikalisme dengan cara-cara berikut: Pertama, menyelenggarakan berbagai pelatihan, lokakarya, seminar, dan kegiatan lain dari perspektif multikultural pendidik. Kedua, terlibat dalam dialog agama dengan pendidik agama, pemimpin atau kelompok agama lainnya. Oleh karena itu, para pendidik agama Islam dan pendidik agama lain dapat saling berkomunikasi dan memahami, yang pada akhirnya akan menumbuhkan apresiasi dan toleransi terhadap agama lain. Ketiga, mengenalkan bacaan atau berbagai referensi pendidikan multikultural dari tahap awal kepada pendidik.

Sasaran multikulturalisme inklusif meliputi: Pertama-tama, tujuan sikap (attitudes) yaitu menumbuhkan kesadaran diri, kepekaan, toleransi, menghargai jati diri budaya dan kemampuan merespon berbagai persoalan dalam masyarakat. Kedua, tujuan kognitif terkait dengan kinerja akademik, mempelajari berbagai bahasa, memperluas pengetahuan tentang budaya tertentu, mampu menganalisis dan menjelaskan perilaku budaya, dan memahami perspektif budaya tertentu.Ketiga, tujuan pengajaran adalah menyampaikan dengan benar berbagai informasi tentang setiap lomba di berbagai buku teks dan pengajaran.Kembangkan strategi tertentu untuk menghadapi masyarakat majemuk.Siapkan alat konseptual untuk komunikasi lintas budaya dan pengembangan keterampilan.Bersiap untuk mengevaluasi teknologi dan mengklarifikasi informasi secara publik tentang nilai-nilai budaya.Selain nilai-nilai tersebut, kurikulum pendidikan juga harus mengadopsi bahasa yang inklusif, komprehensif, dialog tidak terbatas, dan mengutamakan toleransi, sehingga mendorong terbentuknya kelembutan, kesopanan, fleksibilitas, dan kemauan hidup berdampingan dengan berbagai partai politik, agama, serta ras.

Oleh karena itu, yang menjadi model pembelajaran penelitian ini adalah tinjauan kurikulum terhadap nilai-nilai tersebut, meliputi kegiatan ekstrakurikuler, kerjasama 
eksternal, dan proses transformasi nilai ke dalam silabus dan kurikulum. Nilai-nilai inklusivitas dalam penelitian ini adalah cara berpikir, sikap keberagaman, dan respon pengambil kebijakan terhadap fenomena yang ada dengan menekankan pada regulasi serta kurikulum (Ekawati et al., 2018).

Kurikulum merupakan salah satu syarat mutlak serta bagian yang tidak dapat dipisahkan dari pendidikan. Kurikulum mempunyai kontribusi penting, serta berisi tentang bagaimana mengembangkan seluruh kapasitas yang dimiliki oleh pelajar sehingga mampu maju serta dapat menciptakan lulusan yang ber.kualitas dan mampu bersaing didunia luas seperti dikancah MEA(Nugraha, 2016).

Salah satu upaya strategis dalam langkah membentuk lulusan yang berkualitas dan mampu bersaing dikancah MEA. Pengembangan kurikulum pendidikan Islam berisi tentang hal-hal yang dapat membantu menciptakan SDM tinggi.Di dalam kurikulum pendidikan Islam juga mencakup pendidikan yang dapat meningkatkan kecakapan berbahasa bagi lulusan sehingga dapat berkontribusi penuh. Kurikulum juga harus memperhatikan gelombang teknologi serta budaya secara menyeluruh agar lulusan tidak kehilangan jati diri dan identitas budaya bangsa(Nugraha, 2016).

Berdasarkan uraian diatas pengembangan kurikulum seharusnya mengalami perubahan untuk menghadapi persoalan yang terjadi.Salah satu model kurikulum yang ditawarkan ialah pendekatan the grass root model.Model pengembangan ini bersumber dari guru atau dosen untuk pengembangan kurikulum.Hal ini berdasarkan pada pengetahuan guru karena guru yang lebih mengetahui kondisi dan kebutuhan yang diperlukan oleh peserta didik.Pengembangan kurikulum memungkinkan terjadinya kompetisi dalam meningkatkan mutu dan sistem pendidikan sehingga dapat menjawab persolan yang dihadapi.

Deradikalisasaai berbasispendidikan Islam moderat mampu diimplementasikan, dengan prosedur yang mampu dipahami di lapangan.Berawal dari konsep Al-Qur'an yang menganjurkan seseorang berperilaku moderat lalu diturunkan menjadi aspek tindakan. Aspek tindakan ini memiliki berbagai cara sepertipendekatan penanaman nilai, pendekatan moral kognitif, pendekatan analisis dan klarifikasi nilai, serta pendekatan partisipatif action (Ashif, 2020).

Komponen pendidikan Islam harus direkonstruksi supaya sejalan dengan tujuan deradikalisasi.Penunjangnya ialah kurikulum, guru, serta metode mengajar.Perumusan kurikulum pendidikan Islam bermuatan nilai-nilai toleransi ditengah-tengah semakin meningkatnya konflik kekerasan sosial keagamaan.Kurikulum ini ke depannya menjadi denahuntuk guru saat menerangkanmateri ajaran Islam secara utuh serta mudah 
dipahami.Materi pelajaran bercirikan normatif-doktrinal-deduktif harus diimbangi dengan materi yang bercirikan historis-empiris-induktif.

Perlu adanyaperenungan antara materi yang tidak hanya berisikan teks semata, perlu diintegrasikandengan realitas empiris-faktual yang berisikan konteks. Adapun tindakan yang lain untuk pencegahan radikalisasi adalah melalui pendidikan formal pelatihan dan konseling. Upaya yang dilakukan untuk mencegah hal tersebut dikalangan pelajar salah satunya dengan cara mengenalkan pendidikan Islam dan menanamkan nilai nasionalisme pada diri pelajar yang dapat dimasukkan kedalam kurikulum.

Pendidik harus memiliki pemikiran terbuka, berwawasan majemuk, kritis, serta berimbang dibutuhkan untuk ditransferkan kepada peserta didiknya pada saat di sekolah.Melalui daya inovasi dari pendidikselama berinteraksi dengan peserta didik, diharapkan peserta didik menjadi tergugah untuk menerapkan jiwa berkembangnya, menerima ragam perbedaan, serta tumbuh jiwa keterbukaan. Islam dan pendidikan Islam di dalamnya secara tidak langsung telah berupaya untuk mengajarkan dan menanamkan pendidikan karakter atau akhlak mulia yaitu membentuk kepribadian seorang muslim sebagaimana cita-cita Islam yang berdasarkan pada nilai Al-Qur'an dan hadis yang berdialog secara berkelanjutan dengan tradisi serta budaya setempat(Saputra, 2020).

\section{Deradikalisasi Kurikulum di Indonesia}

Undang-Undang Nomor 1 Republik Indonesia mengatur tentang tindak pidana pemberantasan terorisme No. 5 tahun 2018.Terorisme mencontohkan bahwa langkahlangkah preventif dan tegas yang terkandung dalam "UU Terorisme" hanya dapat memiliki celah terkait dengan mengurangi dan menekan penyebaran radikalisme di lembaga pendidikan. Jika ada tanda-tanda aktivitas radikalisme, pemerintah terutama Badan Nasional Penanggulangan Terorisme (BNPT), serta lembaga pendidikan harus menyusun agenda untuk menghapus radikalisme.

Deradikalisasi perlu dilakukan sejak dini, mulai dari tingkat pendidikan dasar, menengah, atas, dan perguruan tinggi dengan cara mengintegrasikan dalam pendidikan agama Islam. Pembelajaran dilakukan dalam pendidikan dengan menerapkan kurikulum yang berlaku saat ini yakni kurikulum 2013. Dalam kurikulum 2013 dilaksanakan di sekolah tertentu sebagai uji coba dengan menanamkan pendidikan karakter. Pembelajaran pendidikan agama Islam dalam kurikulum tersebut, mengharuskan guru membuat rencana pelaksanaan pembelajaran dengan mengintegrasikan nilai keagamaan, seperti menanamkan akidah, memperkuat ibadah, dan mengembangkan akhlak mulia(Mulyasa, 2017).

Badan Nasional Penanggulangan Terorisme-BNPT melakukan tindakan preventif melalui anti radikalisme (ideological deterrence). Untuk itu, telah dibentuk Forum 
Koordinasi Pencegahan Terorisme Daerah (FKPT) di provinsi, pelatihan anti terorisme radikal untuk ormas (ToT) untuk sarjana perguruan tinggi, serta sosialisasi anti terorisme radikal untuk siswa SMA. Sikap pencegahan terorisme dan radikalisme agama di kalangan anak muda harus mengangkat beberapa poin, antara lain:

1) Memperkokoh pendidikan kewarganegaraan dengan menanamkan pemahaman yang mendalam tentang empat pilar kebangsaan, yaitu Pancasila, UUD 1945, NKRI, serta Bhineka Tunggal Ika. Melalui pendidikan kewarganegaraan, generasi muda didorong untuk menjunjung tinggi dan menginternalisasi nilai-nilai luhur yang sejalan dengan kearifan lokal, seperti toleransi antar agama, kebebasan yang bertanggung jawab, gotong royong, kejujuran, cinta tanah air, serta kepedulian antar warga.

2) Membimbing kaum muda untuk berpartisipasi dalam berbagai kegiatan berkualitas tinggi di bidang akademik, sosial, keagamaan, seni, budaya, serta olahraga.

3) Memberikan pemahaman tentang perdamaian dan toleransi beragama, agar generasi muda tidak mudah terjebak radikalisme. Dalam hal ini, peran pendidik di lingkungan sekolah serta tokoh agama di masyarakat diperlukan.

4) Memberikan teladan bagi kaum muda. Pasalnya, jika tidak ada panutan penyelenggara nasional, tokoh agama, serta tokoh masyarakat maka upaya yang diterapkan menjadi sia-sia.

Berdasarkan hasil seminar yang diselenggarakan oleh Pusbangdatin Hukum dan Ham, salah satu program pemberantasan radikal bebas bagi mahasiswa adalah dengan meningkatkan pemahaman, pengamalan dan pengembangan nilai-nilai agama yang benar, serta penguatan pendidikan karakter etnik di sekolah/madrasah. Irfan Idrisselaku Direktur Badan Nasional Penanggulangan Terorisme, mengatakan mata kuliah etnisitas perlu dimasukkan ke dalam kurikulum untuk mencegah penyebaran radikalisme (Balitbang.go.id).

Rencana peningkatan pendidikan karakter sejalan dengan sembilan rencana prioritas dalam rencana Nawacita pemerintahan Jokowi-JK.Salah satunya adalah revolusi karakter bangsa.Hingga akhirnya, Presiden mengeluarkan Peraturan Presiden Nomor 87 tentang pendidikan moral pada tahun 2017. Penguatan Pendidikan Karakter (selanjutnya disingkat PPK) adalah kampanye pendidikan yang menjadi tanggung jawab dinas pendidikan untuk meningkatkan karakter peserta didik dengan mengkoordinasikan partisipasi dan kerjasama antar lembaga pendidikan, keluarga dan masyarakat, serta mengkoordinasikan hati, perasaan, pikiran masyarakat, serta gerakan.

Pemerintah melalui Perpres Nomor 18 tahun 2020 yang ditindaklanjuti melalui KEMENAG RI juga menggalakkan sebuah progam dalam pendidkan yaitu 
mengintegrasikan pendidikan agama Islam yang moderat atau istilah yang dipilih yaitu Moderasi Agama. Kemenag membentuk tim dalam menyusun dan membentuk sebuah regulasi yang akan dimasukkan dan diaplikasikan para lembaga pendidikan. Seperti yang tertera pada desain Moderasi Beragama Tahun 2018 yang disusun oleh Tim Direktorat Pendidikan Agama Islam bahwa ada beberapa poin yang bisa dilakukan dalam deradikalisasi.

1) Penguatan nilai-nilai kebangsaan terintegrasi dengan ajaran/doktrin agama

2) Diseminasi moderasi Islam melalui instruktur kebangsaanpendidik (melalui kegiatankegiatan)

3) Penguatan karakter religius kepada Ketua OSIS atau ketua departemen rohani Islam (ROHIS)

4) Review Kurikulum PAI pada jenjang dasar dan menengah

5) Membuat edaran tentang pengenalan moderasi agama pada siswa baru SMA/SMK dan SMA Kedinasan (sosialisasi dan penguatan keagamaan bekerjasama dengan MUI setempat atau bersama ahli agama/expert).

6) Pemberian bantuan FKG/KKG/MGMP/PokjawasPAI berbasis Moderasi Islam Walaupun secara RUU belum disahkan secara resmi oleh pemangku kebijakan tetapi program deradikalisasi ini sangat mendesak untuk dilaksanakan dan disosialisasikan karena mulai kencangnya arus berita yang banyak memicu perpecahan masyarakat sehingga bisa bepotensi terjadinya perilaku intoleran di Indonesia. Banyak pihak yang mendesak pemerintah untuk mendesain secara baku desain dan model kurikulum deradikalisasi secara menyeluruh, namun masih dalam bentuk wacana dan proses menuju terbentuknya kurikulum tersebut.

\section{KESIMPULAN}

Deradikalisasi kurikulum di Indonesia sangat diperlukan jika melihat menjamurnya paham intoleran di dunia pendidikan dan menyerang kapan pun serta merongrong keutuhan NKRI yang penuh dengan ras, agama, dan masyarakat yang plural.Deradikalisasi dalam pendidikan dapat dilakukan dengan pendekatan pedagogis melalui perencanaan yang matang dalam kurikulum pada pembelajaran pendidikan agama Islam. Deradikalisasi kurikulum di Indonesia sendiri mulai digalakkan oleh pemerintah dengan Program Penguatan Pendidikan Karakter ini sejalan dengan sembilan program prioritas Nawacita Pemerintahan. Kemendikbud mencanangkan program penguatan pendidikan karakter (PPK) dan Kemenag pula penerbitkan permen yang di dalamnya memasukan nilai-nilai deradikalisasi. 


\section{BIBLIOGRAFI}

Achadah, A. (2020). Model Inovasi Pengembangan Kurikulum Pai Untuk Menghadapi Revolusi Industri 4.0. SCAFFOLDING: Jurnal Pendidikan Islam Dan Multikulturalisme, 2(1), 1-10. https://doi.org/10.37680/scaffolding.v2i1.260

Ashif, A. Z. (2020). Penerapan Nilai-Nilai Moderasi Islam Dalam Pembelajaran Fiqih Di Ptkin Menggunakan Konsep Problem Basic Learning. Jipis, 29(01).

Ekawati, E., Suparta, M., \& Sirin, K. (2018). Moderasi Kurikulum Perguruan Tinggi Islam Dalam Deradikalisasi Agama Di Indonesia. Istiqro, 16(01).

Fikriansyah. (2019). Peran Pendidik dalam Upaya Deradikalisasi Paham Keagamaan. Tarbawi Jurnal Ilmu Pendidikan, 15(02), 249-261.

Hergianasari, P. (2019). Konsep Deradikalisasi Pada Pendidikan Berbasis Pembelajaran Terpadu. Scholaria.

Hadi, Usman. (2020). Geger Pembina Ajarkan Tepuk Pramuka 'No Kafir' di Yogya.Diakses tanggal 1 Januari 2021 dari https://news.detik.com/berita-jawa-tengah/d4857145/geger-pembina-ajarkan-tepuk-pramuka-no-kafir-di-yogya.

Isnawan, F. (2018). Program Deradikalisasi Radikalisme dan Terorisme Melalui Nilai-Nilai Luhur Pancasila. FIKRI: Jurnal Kajian Agama, Sosial Dan Budaya, 3(1), 1. https://doi.org/10.25217/jf.v3i1.275

Karwadi, K. (2014). Deradikalisasi Pemahaman Ajaran Islam. Al-Tahrir: Jurnal Pemikiran Islam, 14(1), 139. https://doi.org/10.21154/al-tahrir.v14i1.71

Kisbiyanto, K. (2016). Manajemen Kurikulum Dalam Perspektif Anti-Radikalisme. Addin, 10(1), 181. https://doi.org/10.21043/addin.v10i1.1134

Muhaimin, M., \& et.al. (2010). Manajemen Pendidikan dalam Aplikasinya dalam penyusunan Rencana Pengembangan Sekolah /Madrasah. Kencana Prenada Mulia Grup.

Muhyiddin.(2017). Pembakaran Masjid Diduga karena Muhammadiyah Dituduh Wahabi. Diakses 1 Januari 2021 dari https://republika.co.id/berita/dunia-islam/islamnusantara/17/10/18/oy0dxv396-pembakaran-masjid-diduga-karena-muhammadiyahdituduh-wahabi

Mulyasa. (2017). Pengembangan dan Implementasi Kurikulum. Remaja Rosdakarya.

Musyarrofah, M. (2018). Deradikalisasi Melalui Pendidikan Karakter Berbasis Khazanah Pesantren. Jurnal Mudarrisuna: Media Kajian Pendidikan Agama Islam, 8(1), 46-59.

Nasr, S. H. (1975). Ideals and Realities of Islam. Unwin Paperbacks.

Nugraha, M. T. (2016). Pengembangan Model Kurikulum Pendidikan Agama Islam (PAI) Menuju Masyarakat Ekonomi Asean (MEA). At-Turats, 10(1), 13. 
https://doi.org/10.24260/at-turats.v10i1.447

Pusat Pengembangan Data dan Informasi Penelitian Hukum dan HAM. (2016). Program Deradikalisasi sebagai upaya Pencegahan Terjadinya Tindakan Terorisme di Indonesia. Diakses 1 Januari 2021 dari https://www.balitbangham.go.id/detailpost/programderadikalisasi-sebagai-upaya-pencegahan-terjadinya-tindakan-terorisme-di-indonesia. Saputra, M. N. A. (2020). Pendidikan Profetik Pesantren Rohmatul Umam Bantul di Era Revolusi Industri 4.0. Jurnal Edudeena.

Stark, R. (2003). One True God, Resiko Sejarah Bertuhan Satu, terj. M. Sadat Ismail. Penerbit Qalam dan Nizam Press.

Sisdiknas.(2003). UU No. 20 Tahun 2003 Tentang Sistem Pendidikan Nasional.Kemendikbud. Sugiyono. (2018). Metode Penelitian Kombinasi (Mix Methods). Alfabeta.

Wahyono, Deni. (2020).Viral Disdik Babel Wajibkan Siswa Baca Buku Felix Siauw, Akhirnya Dibatalkan. Diakses 1 Januari 2021 dari https://news.detik.com/berita/d5197583/viral-disdik-babel-wajibkan-siswa-baca-buku-felix-siauw-akhirnyadibatalkan. 